\title{
Genetic structure of a natural oak community in central Italy: Evidence of gene flow between three sympatric white oak species (Quercus, Fagaceae)
}

\author{
G. Antonecchia, P. Fortini, O. Lepais, S. Gerber, P. Léger, G.S. Scippa, V. Viscosi
}

Antonecchia G., Fortini P., Lepais O., Gerber S., Legér P., Scippa G.S., Viscosi V., 2015. Genetic structure of a natural oak community in central Italy: Evidence of gene flow between three sympatric white oak species (Quercus, Fagaceae). Ann. For. Res. 58(2): 205-216.

Abstract. Incomplete reproductive barriers between species, especially in sympatric areas where several species coexist, may result in hybridization and an increase in genetic diversity. Here we assessed the amount of genetic diversity in a community of three interfertile and sympatric European oaks (Quercus frainetto Ten., Q. petraea Liebl. Matt. and Q. pubescens Willd.) situated in central Italy. We used 11 microsatellite markers derived from Expressed Sequence Tag (EST-SSRs) and we implemented a Bayesian clustering analysis to assign individuals to species or hybrids. All genotyped loci were polymorphic for all the species and three genetic clusters corresponding to each species were detected. Significant differences and a higher level of gene flow were observed between the three oak species. Occurrence of hybrids varied markedly within the studied area: hybrids between $Q$. petraea and $Q$, pubescens were the most frequent, while hybrids between $Q$. petraea and $Q$. frainetto were particularly rare. $Q$. pubescens and $Q$. petraea showed the highest number of alleles compared to $Q$. frainetto, which was characterized by a low number of private, but highly frequent, alleles. However, $Q$. frainetto showed a lower genetic diversity and a stronger reproductive isolation from the other two oak species. Keywords bayesian clustering analysis, interspecific gene flow, Italian Peninsula, hybridization, Quercus frainetto, $Q$. petraea, $Q$. pubescens, ESTSSRs

Authors. Gaby Antonecchia, Paola Fortini, Gabriella Stefania, Scippa-Università degli Studi del Molise, Cda Fonte Lappone IT-86070 Pesche, Italia; Olivier Lepais - INRA, UMR 1224 ECOBIOP, F-64310 Saint Pée sur Nivelle, France, Université Pau and Pays Adour, UMR 1224 ECOBIOP, F-64600 Anglet, France; Sophie Gerber - INRA, UMR 1202 BIOGECO, 69 route d'Arcachon, F-33612 Cestas cedex, France, Université de Bordeaux, F-33612 Cestas cedex, France; Patrick Léger - INRA, UMR 1202 BIOGECO, 69 route d'Arcachon, F-33612 Cestas cedex, France; Vincenzo Viscosi (vincenzo.viscosi@istruzione. it) - MIUR, Department for Instruction, Institute “O. D’Uva”, IT-86090 Castelpetroso, Italia.

Manuscript received February 12, 2015; revised July 10, 2015; accepted July 17, 2015; online first July 20, 2015. 


\section{Introduction}

Hybridization occurs in areas where interfertile taxa coexist and represents an important biological factor in the evolution of plant species (Rieseberg 1997). White oaks (genus Quercus, section Quercus sensu Nixon 1993) are usually sympatric in different areas of their distribution, a configuration that tends to favour interspecific gene flow (Rushton 1993, Williams et al. 2001, Tovar-Sánchez \& Oyama 2004, Lepais et al. 2009). The identification of hybrids in Quercus genus can be difficult because of the high morphological variability of hybrids, even when the morphological characters of the parental species are well described. This leads to a high morphological variability and brings confusion in the taxonomy of this group; in the Italian peninsula this is especially true for Q. pubescens (Di Pietro et al. 2012). In such a case genetic markers provide an invaluable tool to determine the relative genetic contribution from various parental species and to estimate the incidence of hybridization.

Oak reproductive system, gene flow and hybridization dynamics of European white oaks has been intensively studied in different areas of sympatry (Muir \& Schlötterer 2005, Curtu et al. 2007a, Curtu et al. 2007b, Gugerli et al. 2007, Lepais et al. 2009, Lòpez de Heredia et al. 2009, Salvini et al. 2009, Viscosi et al. 2009, 2012, Neophytou et al. 2010, Lind \& Gailing 2013). On a continental scale, white oaks are characterized by high level of gene flow and high rates of hybridization (Gerber et al. 2014), which could be increased by environmental changes and disturbed environments (Legache et al. 2013).

European white oak species have plastic reproductive barriers characterized by postmating prezygotic barriers stronger than postzygotic barriers (Abadie et al. 2012, Lepais et al. 2013). In addition, the frequency and direction of hybridization is affected by several factors such as species abundance, forest management and local environmental conditions (Lepais et al. 2009) underpinning potential impact of ecological factors on evolutionary processes.

In Europe, evidences of hybridization among sympatric white oaks were reported for many ecological regions and different species using nuclear molecular markers such as microsatellites SSRs. Nuclear SSRs are the markers of choice to estimate the amount of intraspecific and interspecific gene flow because of their high number of alleles and polymorphism level (Guichoux et al. 2011a). Additionally, nuclear SSRs are very valuable because they present variation in different genomic regions including random genomic region (non-genic nSSR) or genic region (EST-SSR) and thus can provide different information about the genomic context of the level of intra- and interspecific variation. Since such markers are highly transferable among related white oak species they represent useful tools to estimate neutral and potentially adaptive genic variation and to detect different pattern of gene flow and local adaptations (Neophytou et al. 2010, Lind \& Gailing 2013, Guichoux et al. 2013). Such genetic markers should represent useful tools to estimate neutral and potentially adaptive genic variation to detect different patterns of gene flow and local adaptations (Neophytou et al. 2010, Lind \& Gailing 2013, Guichoux et al. 2013). EST-SSRs are advantageous if compared to genomic SSRs because allow to study expressed genomic regions and because they are characterized by a better conservation of primer sites, which are easily transferable across closely related species (Durand et al. 2010).

While the use of fast and cost effective PCR multiplexing technique was limited in number of loci (Dzialuk et al. 2005, Lepais et al. 2006), two powerful multiplexes were lately developed for white oaks ( $Q$. petraea and $Q$. robur). These were a 12-plex of EST-SSRs and an 8plex of genomic SSRs and showed to work well for other species in the Fagaceae family (Guichoux et al. 2011b). These techniques are usually combined with the use of Bayesian 
clustering analysis allowing to study hybridization, to increase understanding of hybridization pattern across the white oak species. Indeed, while $Q$. robur and $Q$. petraea have been extensively studied, the European oak forests often consisted of a species communities composed of other species that usually remain notably understudied. A few exceptions can however be considered, for instance in West-Central Romania, a community of $Q$. frainetto, $Q$. petraea, $Q$. pubescens and $Q$. robur which showed natural hybridization, introgression and different levels of ancient gene flow among species (Curtu et al. 2007a, 2007b). In Spain, the individual admixture rate was assessed in mixed oak forests of $Q$. petraea and $Q$. pyrenaica revealing low levels of introgression between these two species (Valbuena-Carabaña et al. 2007). In CentralNorthern Italy a study on mixed forests of $Q$. pubescens and $Q$. petraea indicated the presence of interspecific gene flow and asymmetrical introgression that was probably caused by the relative species abundance (Salvini et al. 2009). In France a study on $Q$. petraea, Q. pubescens, $Q$. pyrenaica and $Q$. robur showed evidence of hybridization among species and high variation in the hybridization level between sites (Lepais et al. 2009). In a study of neighboring stands of $Q$. petraea and $Q$. robur, along an ecological gradient from Germany to Balkan were detected effects of gene flow and adaptations on genomic SSRs loci (Neophytou et al. 2010). The Italian peninsula represented an important refuge area during the Quaternary era (Brewer et al. 2002, Petit et al. 2003) and is actually the southern margin of a natural distribution range of several white oaks species (i.e. $Q$. frainetto, $Q$. petraea, $Q$. pubescens and $Q$. robur). In spite of the importance of this area for the European white oaks, there is little information on the genetic differentiation and on the hybridization patterns within such a complex oaks species community in the region. This paper aims to improve the knowledge on the genetic relationships among three sympatric white oaks (Quercus frainetto, $Q$. petraea, $Q$. pubescens) in an Italian area representing both an ancient glacial refuge and the present rear edge of the distribution area of these species. Quercus pubescens is widespread across the Italian peninsula owning to its wide ecological requirement and preference for xeric soil condition. Q. petraea geographical distribution is scattered in central-southern Italy and this species is usually not a dominant tree within woody communities. Finally $Q$. frainetto has a southern distribution in Italy and is a poorly genetically characterized species among the European white oaks. Indeed only a few papers reported information about its genetic variation (i.e. Curtu et al. 2007a, 2011, 2014, Fortini et al. 2009, Viscosi et al. 2012, Fortini et al. 2013).

Using newly developed genetic markers, we inferred past gene flow by assigning individuals as purebred or admixed genotypes (putative hybrids) and assessing the genetic differentiation between species in these rear edge populations.

\section{Materials and methods}

\section{Plant material}

A total of 273 oak trees were sampled in a mixed forest community (680 ha) of CentralSouthern Italy (Fig. 1) containing three white oak species (Q. frainetto, Q. petraea and Q. pubescens) associated with $Q$. cerris L. and other tree species, as Acer campestre L., Acer opalus Mill., Acer cappadocicum Gled. subsp. Lobelii (Ten.) Murrai, Carpinus betulus L., Fraxinus excelsior L., Fraxinus ornus L., Fagus sylvatica L., Tilia cordata Mill. and Castanea sativa Mill. The studied natural plant community is located in an important site for the Mediterranean biogeographical region and in these areas mostly occur as high forests, while coppice areas are less common. It represents a community importance site (site code: IT7222295) for 


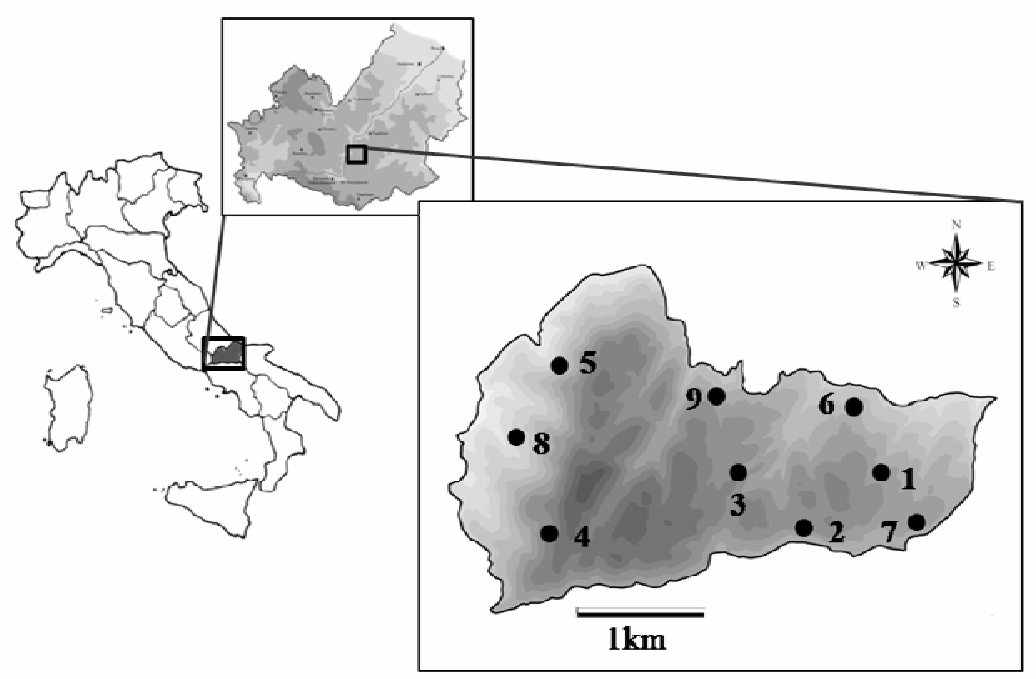

Figure 1 Localization of the study area in Italian peninsula and Molise region

the Mediterranean biogeographical region and is characterized by a high natural conservation level of a deciduous oak community (habitat code: 91M0).

Specimens were collected in nine 50 by 50 meters plots (Viscosi \& Fortini 2011, Viscosi et al. 2012) where at least 30 mature individuals were randomly sampled. Previously, the entire study area has been intensively studied by phytosociological relevés (Mucina et al. 2000); thus, the environmental data, the plant species and their relative covering were recorded. The plots have been identified as representative of homogeneous areas for vegetation and micro-environmental factors (Viscosi $\&$ Fortini 2011). In particular, the natural area was characterized by three distinct microclimatic sectors. The plots dominated by $Q$. petraea were located in the northern sector of the studied area and principally characterized by the north-facing hill side; plots located in the southern sector on the studied area were characterized by warmer and dryer microclimatic conditions and by a rare occurrence of $Q$. petraea and a dominance (or co-dominance) of $Q$. frainetto and $Q$. pubescens; finally, a small sector, was characterized by calcareous sub- strates and dryer microclimatic conditions and dominated by $Q$. pubescens.

Morphological identification was performed following Schwarz (1993), Curtu et al. (2007) and Fortini et al. (2009). In addition, the leaves of all samples were observed using an electron microscope (Fortini et al. 2013). Specimens assigned to $Q$. petraea had glabrous young twigs and stellate trichomes on the abaxial leaf surface; $Q$. frainetto and $Q$. pubescens specimens had pubescent young twigs and fasciculate trichomes. Leaves with more than eight pairs of parallel lateral veins were indicative of $Q$. frainetto; while specimens with fewer than eight pairs of lateral veins were classified as $Q$. pubescens. Individuals with atypical morphology were considered as hybrids.

\section{DNA extraction and amplification}

DNA was extracted from $0.5 \mathrm{~g}$ of $-80^{\circ} \mathrm{C}$ stored leaves using spin columns of "Invisor ${ }^{\circledR}$ Spin Plant Mini Kit" and following the protocol manufacturer's instructions. Twelve nuclearmicrosatellite loci (EST-SSRs: "PIE020, PIE223, PIE152, PIE242, PIE102, PIE243, PIE239, PIE227, PIE271, PIE267, PIE258, PIE215") 
were genotyped as described elsewhere (Durand et al. 2010, Guichoux et al. 2011b). PCR reactions were performed in a DNA Engine Tetrad (MJ Research Bio-Rad) thermocycler and PCR products were run in an ABI 3730xl capillary sequencer (Applied Biosystems) at the Genome-Transcriptome facility of Bordeaux (Cestas, FR) using Genescan 600 LIZ internal size standard (Applied Biosystems). Alleles were scored using STRand software version 2.3.106 (Toonen \& Hughes 2001) and allele binning were performed as described in Guichoux et al. (2011a). We checked the presence of null alleles, stuttering and allele dropout using the Micro-checker v2.2.3 with 1000 randomizations and a $95 \%$ confidence interval (Van Oosterhout et al. 2004).

\section{Statistical analysis}

Genetic assignment was performed without prior information on location and morphological classification by means of Bayesian clustering analysis using Structure ver. 2.3.1 (Pritchard et al. 2000; Falush et al. 2003). We used the Admixture model and the Correlated Allele Frequencies model. The ALPHA Dirichlet parameter for degree of admixture has an initial value of 1.0 with a standard deviation of proposal for updating Alpha of 0.025 . We assumed a frequency model with different value of $\mathrm{F}_{\mathrm{ST}}$ for different populations (prior mean of $\mathrm{F}_{\mathrm{ST}}$ for populations of 0.01 and standard deviation of 0.05 ) using a constant lambda of 1.0. Structure was run from 1 to 9 number of clusters $(k)$, with ten repetitions for every $k, 100,000$ burnin periods and 1,000,000 MCMC repeats after burning. Following the $\Delta k$ method (Evanno et al. 2005), the package CorrSieve (Campana et al. 2011) was used to detect the most likely number of clusters. Individuals were assigned to species or putative hybrid by means of the estimated membership coefficient (Q). Following current practices (e.g. Lepais et al. 2009) individuals with probabilities above 0.90 to belong to one clusters $(\mathrm{Q} \geq 0.900)$ were as- signed as purebred while individuals with intermediated admixture coefficient $(0.100 \geq \mathrm{Q}$ $\geq 0.900$ ) were assigned as hybrids.

AMOVA (Analysis of Molecular Variance) was performed to analyze the hierarchical partition of genetic variation and to test the degree of genetic differentiation between species. AMOVA was performed, on the pure species, with the software package GenAlEx version 6.4 (Peakall \& Smouse 2006) and the significance of $\mathrm{F}_{\mathrm{ST}}$ was tested by 9999 random permutations. The following summary statistics were estimated within populations using GenAlex 6.4: average number of alleles per locus $\left[N_{\mathrm{a}}\right]$, average number of effective alleles per locus $[\mathrm{Ne}]$, observed heterozygosity $\left[\mathrm{H}_{\mathrm{o}}\right]$, expected heterozygosity $\left[H_{\mathrm{e}}\right]$ and inbreeding coefficient $\left[F_{\text {is }}\right]$. In addition, allelic richness [Rs], a diversity measure which is "independent of the population size" (Petit et al. 1998), obtained after rarefaction was computed for each population and locus using the program FSTAT v. 2.9.3 (Goudet 2001).

\section{Results}

A total of 268 out of 273 sampled individuals were successfully genotyped. Micro-checker (Van Oosterhout et al. 2004) revealed the presence of a significant amount of null allele at the locus PIE258 for the three species and was thus removed from the subsequent analyses.

All remaining loci were polymorphic with a total of 127 alleles varying from 69 to 260 bp (Table S1) and, in general, fragment sizes matched with the relative SSR reference size, as described in Guichoux et al. (2011b).

Bayesian clustering analysis allowed the identification of three genetic clusters corresponding to the three morphological species: $Q$. frainetto, $Q$. petraea and $Q$. pubescens. Overall, $Q$. petraea was the most frequent species representing $35.82 \%$ of the individuals followed by $Q$. frainetto and $Q$. pubescens, which represent $20.90 \%$ and 20.52 , respective- 
ly (Table 1). Hybrids (including backcrossed and $F_{1}$ hybrids) varied considerably ranging from $3.33 \%$ to $42.86 \%$, between plot 8 (1 hybrid) and 5 (12 hybrids) having the minimum and the maximum numbers of hybrids, respectively. In detail, we identified 29 petraea $\mathrm{x}$ pubescens, 16 frainetto $\mathrm{x}$ pubescens, 7 petraea $\mathrm{x}$ frainetto and 9 trihybrids petraea $\mathrm{x}$ pubescens $\mathrm{x}$ frainetto (Table 1). It appeared that 15 morphologically intermediate specimens were ge- netically pure (8 Q. pubescens, 5 Q. frainetto and $2 Q$. petraea) while 36 trees morphologically classified as pure species ( $23 Q$. petraea, $7 Q$. frainetto and $6 Q$. pubescens) were putative hybrids.

Mean allelic richness over loci (Rs) ranged between 6.53 and 9.55 (Table 2) with $Q . p u$ bescens presenting the higher allelic richness (Table 2). Expected heterozygosity (He) varied from 0.65 to 0.72 in pure species and very

Table 1 Results of genetic assignment of individuals per plot. For each genotype (pure or mixed) number of individuals (up) and their percentage (down) were reported

\begin{tabular}{|c|c|c|c|c|c|c|c|c|}
\hline Stand & $\mathrm{N}$ & fra & pet & $p u b$ & fraXpet & fraXpub & petXpub & pubXpetXfra \\
\hline 1 & 32 & $\begin{array}{l}8 \\
(25.00) \\
\end{array}$ & $\begin{array}{l}18 \\
(56.25) \\
\end{array}$ & - & $\begin{array}{l}1 \\
(3.13)\end{array}$ & - & $\begin{array}{l}3 \\
(9.38) \\
\end{array}$ & $\begin{array}{l}2 \\
(6.25)\end{array}$ \\
\hline 2 & 30 & $\begin{array}{l}11 \\
(36.67)\end{array}$ & $\begin{array}{l}1 \\
(3.33)\end{array}$ & $\begin{array}{l}10 \\
(33.33)\end{array}$ & $\begin{array}{l}1 \\
(3.33)\end{array}$ & $\begin{array}{l}4 \\
(13.33)\end{array}$ & $\begin{array}{l}2 \\
(6.67)\end{array}$ & $\begin{array}{l}1 \\
(3.33)\end{array}$ \\
\hline 3 & 30 & $\begin{array}{l}3 \\
(10.00)\end{array}$ & $\begin{array}{l}20 \\
(66.67)\end{array}$ & - & $\begin{array}{l}1 \\
(3.33) \\
\end{array}$ & - & $\begin{array}{l}6 \\
(20.00)\end{array}$ & - \\
\hline 4 & 30 & $\begin{array}{l}9 \\
(30.00)\end{array}$ & $\begin{array}{l}2 \\
(6.67)\end{array}$ & $\begin{array}{l}10 \\
(33.33)\end{array}$ & - & $\begin{array}{l}7 \\
(23,33)\end{array}$ & $\begin{array}{l}1 \\
(3.33)\end{array}$ & $\begin{array}{l}1 \\
(3.33)\end{array}$ \\
\hline 5 & 28 & $\begin{array}{l}2 \\
(7.14)\end{array}$ & $\begin{array}{l}11 \\
(39.29)\end{array}$ & $\begin{array}{l}3 \\
(10.71)\end{array}$ & - & $\begin{array}{l}3 \\
(10.71)\end{array}$ & $\begin{array}{l}7 \\
(25.00)\end{array}$ & $\begin{array}{l}2 \\
(7.14)\end{array}$ \\
\hline 6 & 30 & $\begin{array}{l}1 \\
(3.33)\end{array}$ & $\begin{array}{l}23 \\
(76.67)\end{array}$ & - & $\begin{array}{l}1 \\
(3.33)\end{array}$ & - & $\begin{array}{l}4 \\
(13.33)\end{array}$ & $\begin{array}{l}1 \\
(3.33)\end{array}$ \\
\hline 7 & 30 & $\begin{array}{l}20 \\
(66.67)\end{array}$ & $\begin{array}{l}3 \\
(10.00)\end{array}$ & $\begin{array}{l}3 \\
(10.00)\end{array}$ & $\begin{array}{l}2 \\
(6.67)\end{array}$ & $\begin{array}{l}2 \\
(6.67)\end{array}$ & - & - \\
\hline 8 & 30 & - & - & $\begin{array}{l}29 \\
(96.67)\end{array}$ & - & - & $\begin{array}{l}1 \\
(3.33)\end{array}$ & - \\
\hline 9 & 28 & $\begin{array}{l}2 \\
(7.14)\end{array}$ & $\begin{array}{l}18 \\
(64.29) \\
\end{array}$ & - & $\begin{array}{l}1 \\
(3.57)\end{array}$ & - & $\begin{array}{l}5 \\
(17.86) \\
\end{array}$ & $\begin{array}{l} \\
(7.14) \\
\end{array}$ \\
\hline Total & 268 & $\begin{array}{l}56 \\
(20.90)\end{array}$ & $\begin{array}{l}96 \\
(35.82)\end{array}$ & $\begin{array}{l}55 \\
(20.52)\end{array}$ & $\begin{array}{l}7 \\
(2.61)\end{array}$ & $\begin{array}{l}16 \\
(5.97)\end{array}$ & $\begin{array}{l}29 \\
(10.82)\end{array}$ & $\begin{array}{l}9 \\
(3.36)\end{array}$ \\
\hline
\end{tabular}

Table 2 Genetic diversity of species

\begin{tabular}{lllllllllll}
\hline Species & $\mathrm{N}$ & $\mathrm{N}_{\mathrm{a}}$ & $\mathrm{N}_{\mathrm{a}}$ Freq. $\geq 5 \%$ & $\mathrm{Ne}$ & $\mathrm{I}$ & Private alleles & $\mathrm{R}_{\mathrm{s}}$ & $\mathrm{H}_{\mathrm{e}}$ & $\mathrm{H}_{\mathrm{o}}$ & $\mathrm{F}_{\mathrm{is}}$ \\
\hline Q. frainetto & 56 & 6.64 & 4.09 & 3.28 & 1.36 & 0.18 & 6.53 & 0.65 & 0.63 & 0.04 \\
Q. petraea & 96 & 9.00 & 4.55 & 4.10 & 1.52 & 0.55 & 7.90 & 0.69 & 0.67 & 0.01 \\
Q. pubescens & 55 & 9.46 & 4.91 & 4.82 & 1.68 & 0.55 & 9.22 & 0.72 & 0.72 & 0.001 \\
\hline
\end{tabular}

Note. Abbreviations: $\mathrm{N}$ - number of individuals, $\mathrm{Na}$ - mean number of alleles per loci, $\mathrm{Ne}$ - effective allelic number, I - Shannon's information index, Rs - mean allelic richness over loci obtained after rarefaction to 46 diploid individuals, He - expected heterozygosity unbiased for sample size, Ho - observed heterozygosity, Fis - inbreeding coefficient obtained by 9999 bootstraps of the individuals within species. 
similar values between observed heterozygosity (Ho) and expected heterozygosity (He) indicated an Hardy-Weinberg equilibrium. This was confirmed by the low fixation index values (Fis: Q. frainetto: $0.035 ;$ Q petraea: $0.011 ; Q$. pubescens: 0.038) indicating no significant heterozygosity deficit for each species.

Private alleles were also identified in $Q . p u$ bescens and in $Q$. petraea while a lower number were found in $Q$. frainetto (Table 2; Table S3). Moreover, $48.03 \%$ of all alleles were common in the three species investigated: $Q$. petraea and $Q$. pubescens shared most common frequent alleles $(70.97 \%$ of common alleles) while $Q$. frainetto shared only $12.90 \%$ with $Q$. petraea and $16.13 \%$ with $Q$. pubescens.

The AMOVA showed that the percentage of molecular variance is mostly distributed within the species ( $86 \%$ of total variance) while a smaller but significant portion of genetic variability was explained by variance among species $\left(14 \%\right.$ of total variance; $\mathrm{F}_{\mathrm{ST}}=0.137 ; P$ $<0.001)$. In addition, pairwise AMOVA indicated significant differences between species $(\mathrm{P}<0.001)$ with the higher differentiation observed between $Q$. frainetto and $Q$. petraea
$\left(\mathrm{F}_{\mathrm{ST}}=0.165\right)$, followed by the pair $Q$. pubescens and $Q$. petraea $\left(\mathrm{F}_{\mathrm{ST}}=0.122\right)$ and, finally $Q$. frainetto and $Q$. pubescens $\left(\mathrm{F}_{\mathrm{ST}}=0.115\right)$.

The overall genetic composition of the sample was heterogeneous (Fig. 2) due to the species composition of the plots (Fig. 3). In fact, five plots consisted in majority of $Q$. petraea. On the other side, three plots were characterized by a greater proportion of $Q$. frainetto while only one plot was mostly composed of Q. pubescens. In general, all plots presented more than $70 \%$ of purebred individuals at the exception of plot 5 (only $57.14 \%$ ). Purebred $Q$. frainetto and $Q$. petraea were found in all plots, except in a plot that only contained purebred $Q$. pubescens. Purebred Q. petraea dominated most of the plots, while $Q$. frainetto was highly dominant only in a plot $(66.67 \%)$ and co-dominant with $Q$. pubescens in another plot.

Different mixtures of hybrid genotypes were detected in the plots. Mixed $Q$. petraea x $Q$. pubescens genotypes were widespread and they were detected also for the plots without the two parental species. In contrast, hybrid $Q$. frainetto x $Q$. petraea genotypes were detect-

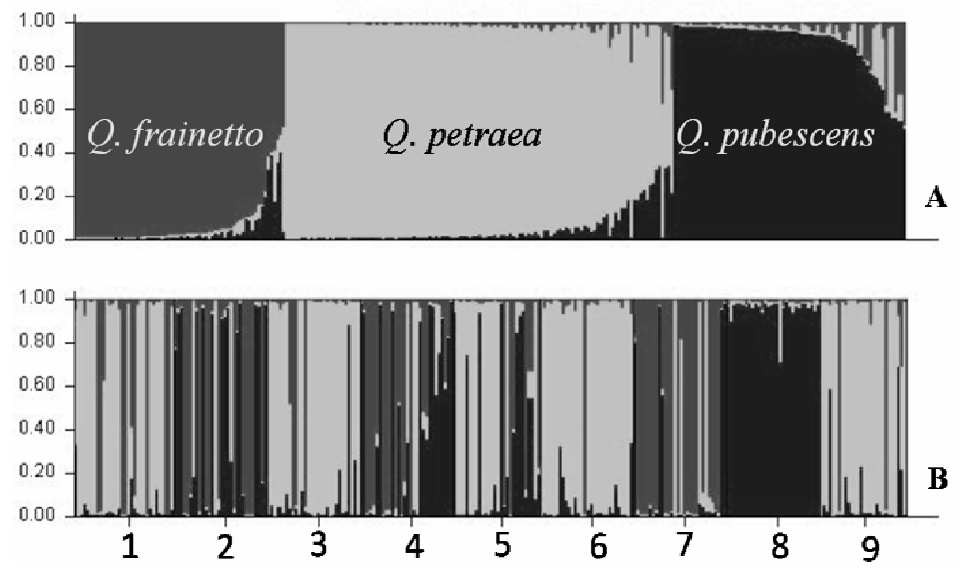

Figure 2 Genetic assignment without any a priori information obtained with Structure clustering analysis. (2A) Clustering of individuals to three different genetic clusters with decreasing admixture coefficient Q (2B) Clustering of individuals of different stands separated by black lines 




Figure 3 Geographical location and genetic structure of the plots

ed in plots where both parental species were found as purebred (Fig. 3). This was observed also for $Q$. frainetto x $Q$. pubescens hybrids that were detected only in plots where purebreds of both parental species were found (Fig. 3). Finally, mixed genotypes characterized by a significant contribution of all three pure species were found in plots that were composed by purebred $Q$. frainetto and $Q$. petraea, while purebred $Q$. pubescens were found only in two plots (Fig. 3).

\section{Discussion}

The analysis of gene flow between sympatric white oak species is important to understand the dynamics of hybridization patterns (Lepais et al. 2009, Lepais \& Gerber, 2011). In particular, by using genetic assignment without any a priori information (Pritchard et al. 2000, Duminil et al. 2006) many studies highlighted different levels of hybridization rate among European white oak species (Valbuena et al. 2005, Gugerli et al. 2007, Curtu et al. 2007b, Salvini et al. 2009, Lepais et al. 2009, Viscosi et al. 2012, Guichoux et al. 2013).

Analysis of molecular variance indicated that the largest percentage of molecular variance explained the differences within species and the pairwise computation highlighted that all the species were significantly differentiated. In particular, the degrees of differentiation $\left(\mathrm{F}_{\mathrm{ST}}\right)$ were similarly between $Q$. petraea $-Q$. pubescens $\left(\mathrm{F}_{\mathrm{ST}}=0.122\right)$ and $Q$. frainetto $-Q$. pubescens $\left(\mathrm{F}_{\mathrm{ST}}=0.115\right)$, while $Q$. frainetto $-Q$. petraea $\left(\mathrm{F}_{\mathrm{ST}}=0.165\right)$ showed the greatest differentiation. These results were coherent with similar studies on European oaks but the average $\left(\mathrm{F}_{\mathrm{ST}}=0.137\right)$ and pairwise differentiation among these three species were higher because of the difference in types of sampling and genetic markers. In particular, Curtu et al. (2006) reported a significant $\mathrm{F}_{\mathrm{ST}}(0.096)$ among four white oak species; the greatest differentiation was observed between $Q$. robur and $Q$. frainetto $\left(\mathrm{F}_{\mathrm{ST}}=0.168\right)$ while the lowest genetic differences was between $Q$. pubescens with $Q$. petraea $(0.045)$ and with $Q$. frainetto $(0.050)$. In addition, Curtu et al. (2011) reported significant differences $\left(\mathrm{F}_{\mathrm{ST}}=0.067\right)$ between $Q$. frainetto and $Q$. pubescens. In Fortini et al. (2009), the greatest differentiation was observed between $Q$. robur and $Q$. frainetto $\left(\mathrm{F}_{\mathrm{ST}}\right.$ $=0.242$ ), while $Q$. petraea and $Q$. pubescens $\left(\mathrm{F}_{\mathrm{ST}}=0.114\right)$ were the lowest differentiated; 
however, the differentiation of $Q$. frainetto with $Q$. petraea $\left(\mathrm{F}_{\mathrm{ST}}=0.160\right)$ was higher than with $Q$. pubescens $\left(\mathrm{F}_{\mathrm{ST}}=0.142\right)$. Salvini et al. (2009) reported a low and significant differentiation $\left(\mathrm{F}_{\mathrm{ST}}=0.076\right)$ between $Q$. petraea and $Q$. pubescens, suggesting that, despite gene flow, the interspecific reproductive barriers contribute to species integrity. Thus, a high differentiation could indicate a greater phylogenetic distance between pair of species; while the low genetic differentiation between species could be a result of higher gene flow rates between species that diverged more recently (Curtu et al. 2006).

Individuals assigned to pure species were the most frequent (77.24\%) while the admixed genotypes represented a low percentage. Different types of hybrids were detected: hybrids between $Q$. petraea and $Q$, pubescens were the most frequent while the hybrids between $Q$. petraea and $Q$. frainetto were particularly rare. Besides, the low number of hybrids detected in the area could be explained by the hypothesis that pure individuals should be more adapted to local environmental conditions (Lepais et al. 2009). In addition, such observation could be due to the existence of strong reproductive barriers among species (Abadie et al. 2012, Lepais et al. 2013). In fact, previous studies of different oak species revealed that interspecific gene flow was relatively common but often asymmetric and intermediate forms and hybrids were mostly located at the environmental edges of the species respective ecological niches (Lind \& Gailing 2013). This supports the hypothesis that white oaks are not totally reproductively isolated and that genes exchange producing different hybridization patterns may have potential evolutionary consequence. Differences in hybridization rates among sympatric species at different sites could result from several factors, such as species abundance, environmental factors, ecological species preferences, species geographic distribution and anthropic activities (Lepais et al. 2009, Gerber et al. 2014). In addition, perturbing the spatial structure of communities and decreasing the density of conspecifics increase the hybridization rates in natural oak communities (Legache et al. 2013). Differences in rates of hybridization among the oak communities indicates the presence of both pre- and postzygotic barriers that can be variable in relation to diverse ecological conditions and also during oaks recolonization after the glaciations (Abadie et al. 2012). Prezygotic and postzygotic barriers contribute differently to reproductive isolation in oak species and the strongest contribution of prezygotic isolation probably results from the reinforcement phenomena, due to selection against hybrid formation (Lepais et al. 2013).

In addition, the within species genetic diversity and its potential relationship with interspecific gene flow were studied. $Q$. pubescens and $Q$. petraea had the highest number of alleles compared to $Q$. frainetto and the latter species was also characterized by a low number of private, but highly frequent, alleles. This was in sharp contrast with the higher number of private alleles found in $Q$. petraea and $Q$. pubescens, which also shown similar levels of genetic differentiation when compared to $Q$. frainetto. A likely explanation for this pattern may be that the higher number of common alleles shared between $Q$. petraea and $Q$. pubescens indicates a more extensive and long-term gene flow between these two species.

In contrast, the low genetic diversity found in $Q$. frainetto and a low rate of interspecific mating between this species and $Q$. petraea or $Q$. pubescens could be temptingly explained by a stronger reproductive barrier between $Q$. frainetto and the other species (Curtu et al. 2011). However differences in rates of interspecific gene flow for this species may also be related to prezygotic barriers such as differences in flowering times and pollen viability (Salvini et al. 2009). 


\section{Conclusions}

A higher proportion of $Q$. pubescens alleles were detected in hybrids, even in plots where $Q$. pubescens individuals were absent. $Q$. pubescens seems to hybridize more frequently with $Q$. petraea than with $Q$. frainetto. Putative hybrids of $Q$. frainetto and $Q$. petraea were extremely rare and a low rate of interspecific mating was found between $Q$. frainetto and $Q$. pubescens. The rarity of hybrids between $Q$. frainetto and $Q$. pubescens could be due to the spatial distributions of species and their relative abundance. The high allelic richness found in $Q$. pubescens may be explained by the propension of this species to hybridize with other species, in particular considering the extensive gene flow recorded with $Q$. petraea in several areas of their distribution.

\section{Acknowledgements}

The authors gratefully acknowledge all reviewers for their helpful comments, which greatly improved the previous versions of this manuscript.

\section{References}

Abadie P., Roussel G., Dencausse B., Bonnet C., Bertocchi E., Louvet J.M., Kremer A., Garnier-Géré P., 2012. Strength, diversity and plasticity of postmating reproductive barriers between two hybridizing oak species (Quercus robur L. and Quercus petraea (Matt) Liebl.). Journal of Evolutionary Biology 25: 157-173. DOI: 10.1111/j.1420-9101.2011.02414.x.

Bacilieri R., Ducousso A., Kremer A., 1995. Genetic, morphological, ecological and phenological differentiation between Quercus petraea (Matt.) Liebl. and Quercus robur $\mathrm{L}$. in a mixed stand of northwest of France. Silvae Genetica 44: 1-9.

Brewer S., Cheddadi R., De Beaulieu J., Reille M., 2002. The spread of deciduous Quercus throughout Europe since the last glacial period. Forest Ecology and Management 156: 27-48. DOI: 10.1016/S03781127(01)00646-6.

Campana M.G., Hunt H.V., Jones H., White J., 2010. CorrSieve: software for summarizing and evaluating
Structure. Molecular Ecology Resources 11: 349-352. DOI: 10.1111/j.1755-0998.2010.02917.x.

Curtu A.L., Gailing O., Finkeldey R., 2007. Evidence for hybridization and introgression within a species-rich oak (Quercus spp.) community. BMC Evolutionary Biology 7: 218-233. DOI: 10.1186/1471-2148-7-218.

Curtu A.L., Gailing O., Leinemann L., Finkeldey R., 2007b. Genetic variation and differentiation within a natural community of five oak species (Quercus spp.). Plant Biology 9: 116-126. DOI: 10.1055/s-2006924542

Curtu A.L., Moldovan I.C., Enescu C.M., Craciunesc I., Sofletea N., 2011. Genetic differentiation between Quercus frainetto Ten and Q. pubescens Willd. in Romania. Notulae Botanicae Horti Agrobotanici Cluj-Napoca 39(1): 275-282.

Curtu A.L., Crăciunescu I., Enescu C.M., Vidalis A., Sofletea N., 2015. Fine-scale spatial genetic structure in a multi-oak-species (Quercus spp.) forest. iForest 8: 324332. DOI: 10.3832/ifor1150-007.

Di Pietro R., Viscosi V., Peruzzi L., Fortini P., 2012. A review of the application of the name Quercus dalechampii. Taxon 61: 1311-1316.

Duminil J., Caron H., Scotti I., Cazal S.O., Petit R.J., 2006. Blind population genetics survey of tropical rainforest trees. Molecular Ecology 15: 3505-3513. DOI: 10.1111/ j.1365-294X.2006.03040.x.

Durand J., Bodénès C., Chancerel E. et al., 2010. A fast and cost-effective approach to develop and map ESTSSR markers: oak as a case study. Genomic 11:570583. DOI: $10.1186 / 1471-2164-11-570$

Dzialuk A., Chybicki I., Burczyk J., 2005. PCR multiplexing of nuclear microsatellite loci in Quercus species. Plant Molecular Biology Reporter 23: 121-128. DOI: 10.1007/BF02772702

Evanno G., Regnaut S., Goudet J., 2005. Detecting the number of clusters of individuals using the software STRUCTURE: a simulation study. Molecular Ecology 14: 2611-2620. DOI: 10.1111/j.1365-294X.2005.02553. $\mathrm{x}$.

Falush D., Stephens M., Pritchard J.K., 2003. Inference of population structure using multilocus genotype data: linked loci and correlated allele frequencies. Genetics 164: 1567-1587.

Fortini P., Viscosi V., Fineschi S., Vendramin G.G., 2009. Comparative leaf surface morphology and molecular data of five oaks of subgenus Quercus Oerst. (Fagaceae). Plant Biosystems 143: 543-554. DOI: 10.1080/ 11263500902722980.

Fortini P., Antonecchia G., Di Marzio P., Maiuro L., Viscosi V., 2013. Role of micromorphological leaf traits and molecular data in taxonomy of three sympatric white oak species and their hybrids (Quercus L.). DOI: 10.1080/11263504.2013.868374. DOI: $10.1080 / 11263$ 504.2013 .868374$.

Gerber S., Chadoeuf J., Gugerli F., Lascoux M., Buiteveld J., Cottrell J., Dounavi A., Fineschi S., Forrest L.L., Fogelqvist J., Goicoechea P.G., Jensen J.S., Salvini 
D., Vendramin G.G., Kremer A., 2014. High rates of gene flow by pollen and seed in oak populations across Europe. PlosOne 9(1): e85130. DOI: 10.1371/journal. pone. 0085130 .

Goudet J., 2001. FSTAT, a program to estimate and test gene diversities and fixation indices. Version 2.9.3. 2001. URL: http://www2.unil.ch/popgen/softwares/ fstat.htm (09 April 2014).

Gugerli F., Walser J.C., Dounavi K., Holderegger R., Finkeldey R., 2007. Coincidence of small-scale spatial discontinuities in leaf morphology and nuclear microsatellite variation of Quercus petraea and Q. robur in a mixed forest. Annals of Botany 99: 713-722. DOI: 10.1093/aob/ mcm006.

Guichoux E., P. Garnier-Géré, L. Lagache, T. Lang, C. Boury, R.J. Petit, 2013. Outlier loci highlight the direction of introgression in oaks. Molecular Ecology 22:450-462. DOI: 10.1111/ mec. 12125 .

Guichoux E., Lagache L., Wagner S., Chaumeil P., Léger P., Lepais O., Lepoittevein C., Malausa T., Revardel E., Salin F., Petit R.J., 2011a. Current trends in microsatellite genotyping. Molecular Ecology Resources 11: 591611. DOI: 10.1111/j.1755-0998.2011.03014.x.

Guichoux E.,Lagache L., Wagner S., Léger P., Petit R.J., 2011b. Two highly validated multiplexes (12-plex and 8-plex) for species delimitation and parentage analysis in oaks (Quercus spp.). Molecular Ecology Resources 11: 578-585. DOI: 10.1111/j.1755-0998.2011.02983.x.

Guichoux E., Garnier-Géré P., Lagache L., Lang T., Boury C., Petit R.J., 2013. Outlier loci highlight the direction of introgression in oaks. Molecular Ecology 22: 450462. DOI: $10.1111 / \mathrm{mec} .12125$.

Lagache L., E.K. Klein, E. Guichoux, R.J. Petit, 2013: Fine-scale environmental control of hybridization in oaks. Molecular Ecology 22: 423-436. DOI: 10.1111/ mec. 12121.

Lepais O., Léger P., Gerber S., 2006. Short Note: High throughput microsatellite genotyping in oak species. Silvae Genetica 55: 4-5.

Lepais O., Petit R.J., Guichoux E., Lavabre J.E., Alberto F., Kremer A., Gerber S., 2009. Species relative abundance and direction of introgression in oaks. Molecular Ecology 18: 2228-2242. DOI: 10.1111/j.1365294X.2009.04137.x.

Lepais O., Gerber S., 2011. Reproductive patterns shape introgression dynamics and species succession within the European white oak species complex. Evolution 651: 156-170.

Lepais O., Roussel G., Hubert F., Kremer A., Gerber S., 2013. Strength and variability of postmating reproductive isolating barriers between four European white oak species. Tree Genetics and Genomes 9: 841-853. DOI: 10.1007/s11295-013-0602-3

Lind J.F., Gailing O., 2013. Genetic structure of Quercus rubra L. and Quercus ellipsoidalis E. J. Hill populations at gene-based EST-SSR and nuclear SSR markers. Tree Genetics and Genomes 3: 707-722. DOI: 10.1007/ s11295-012-0586-4.
Lòpez de Heredia U., Valbuena-Carabana M., Còrdoba M., Gil L., 2009. Variation components in leaf morphology of recruits of two hybridising oaks [Q. petraea (Matt.) Liebl. and $Q$. pyrenaica Willd.] at small spatial scale. European Journal of Forest Resources 128: 543-554. DOI: 10.1007/s10342-009-0302-6.

Mucina L., Schaminée J.H.J., Rodwell J., 2000. Common data standards for recording relevés in field survey for vegetation classification. Journal of Vegetation Science 11: 769-772. DOI: $10.2307 / 3236581$.

Muir G., Schlötterer C., 2005. Evidence for shared ancestral polymorphism rather than recurrent gene flow at microsatellite loci differentiating two hybridizing oaks (Quercus spp.). Molecular Ecology 14: 549-561. DOI: 10.1111/j.1365-294X.2004.02418.x.

Neophytou C., Aravanopoulos F.A., Fink S., Dounavi A., 2010. Detecting interspecific and geographic differentiation patterns in two interfertile oak species (Quercus petraea (Matt.) Liebl. and Q. robur L.) using small sets of microsatellite markers. Forest Ecology and Management 259: 2026-2035. DOI: 10.1016/ j.foreco.2010.02.013.

Nixon K.C., 1993. Infrageneric classification of Quercus (Fagaceae) and typification of sectional names. Annals of Forest Science 50: 25-34. DOI: 10.1051/forest: 19930701 .

Peakall R., Smouse P., 2006. GENEALEX 6: genetic analysis in Excel. Population genetic software for teaching and research. Molecular Ecology Notes 6: 288-295. DOI: 10.1111/ j.1471-8286.2005.01155.x.

Petit R.J., El Mousadik A., Pons O., 1998. Identifying populations for conservation on the basis of genetic markers. Conservation Biology 12: 844-855. DOI: 10.1046/ j.1523-1739.1998. 96489.x.

Petit R.J., Aguinagalde I., de Beaulieu J.L., Bittkau C., Brewer S., Cheddadi R., Ennos R., Fineschi S., Grivet D., Lascoux M., Mohanty A., Müller-Starck G., Demesure-Musch B., Palmé A., Martín J.P., Rendell S., Vendramin G.G., 2003. Glacial Refugia: Hotspots But Not Melting Pots of Genetic Diversity. Science 300: 1563-1565. DOI: 10.1126/science.1083264.

Pritchard J.K., Stephens M., Donnelly P., 2000. Inference of population structure using multilocus genotype data. Genetics 155: 945-959.

Rieseberg L.H., 1997. Hybrid origins of plant species. Annual Review of Ecology, Evolution, and Systematics 28: 359-389. DOI: 10.1146/annurev.ecolsys.28.1.359.

Rushton B.S., 1983. An analysis of variation of leaf characters in Quercus robur L. and Quercus petraea (Matt.) Liebl. population samples from Northern Ireland. Irish Forestry 40: 52-77.

Salvini D., Bruschi P., Fineschi S., Grossoni P., Kjaer E.D., Vendramin G.G., 2009. Natural hybridisation between Quercus petraea (Matt.) Liebl. and Quercus pubescens Willd. Within an Italian stand as revealed by microsatellite fingerprinting. Plant Biology 11: 758-765. DOI: 10.1111/j.1438-8677.2008.00158.x.

Schwarz O. 1993. Quercus L. In: Tutin T.G., Burges 
N.A.,Chater A.O., Edmondson J.R., Heywood V.H., Moore D.M., Valentine D.H., Walters S.M., Webb D.A. (eds.). Flora Europaea. Cambridge University Press, Cambridge, Vol. 1, pp. 72-76.

Toonen R.J., Hughes S., 2001. Increased throughput for fragment analysis on ABI Prism 377 automated sequencer using a membrane comb and STRand software. Biotechniques 31: 1320-1324.

Tovar-Sánchez E., Oyama K., 2004. Natural hybridization and hybrid zones between Quercus crassifolia and Quercus crassipes (Fagaceae) in Mexico: morphological and molecular evidence. American Journal of Botany 91: 1352-1363. DOI: 10.3732/ajb.91.9.1352.

Valbuena-Caraba-a M., Gonzalez-Martinez S.C., Sork V.L., Collada C., Soto A., Goicoechea P.G., Gil L., 2005. Gene flow and hybridisation in a mixed oak forest (Quercus pyrenaica Wild. and Quercus petraea (Matts.) Liebl.) in central Spain. Heredity 95: 457-465. DOI: 10.1038/ sj.hdy.6800752.

Valbuena-Caraba-a M., González-Martínez S.C., Hardy O.J., Gil L., 2007. Fine-scale spatial genetic structure in mixed oak stands with different levels of hybridization. Molecular Ecology 16: 1207-1219. DOI: 10.1111/ j.1365-294X.2007.03231.x.

Van Oosterhout C., Hutchinson W.F., Wills D.P., Shipley P., 2004. Micro-checker: software for identifying and correcting genotyping errors in microsatellite data. Molecular Ecology Notes 4: 535-538. DOI: 10.1111/ j.1471-8286.2004.00684.x.

Viscosi V., Lepais O., Gerber S., Fortini P., 2009. Leaf morphological analysis in four European oak species (Quercus) and their hybrids: a comparison of traditional and new morphometric methods. Plant Biosystems 143:
564-574. DOI: 10.1080/11263500902723129.

Viscosi V., Fortini P., 2011. Leaf shape variation and differentiation in three sympatric white oak species revealed by elliptic Fourier analysis. Nordic Journal of Botany 29: 632-640. DOI: 10.1111/j.1756-1051.2011.01098.x.

Viscosi V., Antonecchia G., Lepais O., Fortini P., Gerber S., Loy A., 2012. Leaf shape and size differentiation in white oaks: assessment of allometric relationships among three sympatric species and their hybrids. International Journal of Plant Sciences 173: 875-884. DOI: 10. 1086/667234.

Williams J.H., Boecklen W.J., Howard D.J., 2001. Reproductive processes in two oak (Quercus) contact zones with different levels of hybridization. Heredity 87: 680690. DOI: 10.1046/j.1365-2540.2001.00968.x.

\section{Supporting Information}

The online version of the article includes the Supp. Info.

Table S1: Alleles, in bp, detected for all ESTSSR in the data set.

Table S2: Characteristics of alleles.

Table S3: Summary of private alleles by species. 